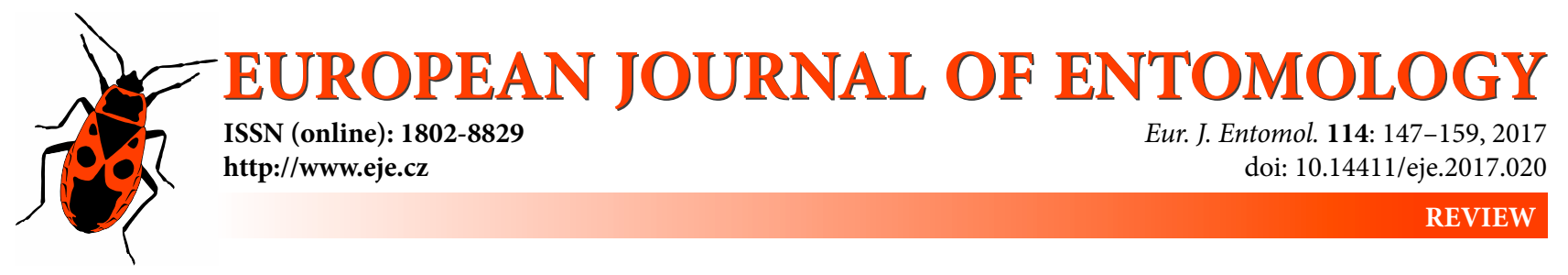

\title{
The diversity of feeding habits recorded for water boatmen (Heteroptera: Corixoidea) world-wide with implications for evaluating information on the diet of aquatic insects
}

\author{
Christian W. HÄDiCKE ${ }^{1, *}$, Dávid RÉdel ${ }^{2,3}$ and Petr KMENT ${ }^{4}$ \\ ${ }^{1}$ University of Rostock, Institute of Biosciences, Chair of Zoology, Universitätsplatz 2, 18055 Rostock, Germany \\ ${ }^{2}$ Institute of Entomology, College of Life Sciences, Nankai University, Weijin Rd. 94, 300071 Tianjin, China; \\ e-mail: david.redei@gmail.com \\ ${ }^{3}$ Hungarian Natural History Museum, Department of Zoology, 1088 Budapest, Baross u. 13, Hungary \\ ${ }^{4}$ National Museum, Department of Entomology, Cirkusová 1740, CZ-193 00 Praha 9 - Horní Počernice, Czech Republic; \\ e-mail: sigara@post.cz
}

Key words. Heteroptera, Corixoidea, aquatic invertebrates, food webs, diet, predation, feeding habits

\begin{abstract}
Food webs are of crucial importance for understanding any ecosystem. The accuracy of food web and ecosystem models rests on the reliability of the information on the feeding habits of the species involved. Water boatmen (Corixoidea) is the most diverse superfamily of water bugs (Heteroptera: Nepomorpha), frequently the most abundant group of insects in a variety of freshwater habitats worldwide. In spite of their high biomass, the importance of water boatmen in aquatic ecosystems is frequently underestimated. The diet and feeding habits of Corixoidea are unclear as published data are frequently contradictory. We summarise information on the feeding habits of this taxon, which exemplify the difficulties in evaluating published data on feeding habits in an invertebrate taxon. It is concluded that Corixoidea are, unlike other true bugs, capable of digesting solid food, but their feeding habits are still insufficiently known. The dominant feeding strategy in this taxon is zoophagy, but several species consume other foods, particularly algae and detritus. Only members of the subfamily Cymatiainae seem to be exclusively predators. In other subfamilies, the diet of different species and different sexes or populations of a single species may vary depending on the food available or is still unknown. We conclude, that a multi-method approach is needed to elucidate the feeding habits of aquatic insects and invertebrates in general.
\end{abstract}

\section{INTRODUCTION}

Studies on feeding niches in different insect groups are an essential backbone for understanding terrestrial and aquatic ecosystems. Aquatic insects are remarkably diverse in terms of their bionomics and specific morphological adaptations (Usinger, 1956; Wallace \& Merritt, 1980; Winterbourn \& Gregson, 1981; Wesenberg-Lund, 1989; Wichard et al., 2013). Aquatic insects occupy a large number of feeding niches and the different taxa are placed into particular guilds [i.e. shredders, scrapers, filterers, etc.; Cummins (1973)]. This simplification into functional feeding groups is a fundamental part of the river continuum concept (Vannote et al., 1980) and some systems to evaluating water quality (Palmer et al., 1996; Pavluk et al., 2000). Information on feeding habits in aquatic insects and other aquatic invertebrates is obtained using different methods, from simple observations (i.e., organisms han- dling certain food and microscopic examinations of gut contents) to advanced DNA-based methods. Morphological and behavioural adaptations of Odonata (Wildermuth \& Martens, 2014), Heteroptera (Savage, 1989; Andersen \& Weir, 2004), Coleoptera (Klausnitzer, 1996), larval Ephermeroptera, Plecoptera and Trichoptera (Wallace \& Merritt, 1980; Merritt \& Wallace, 1981; McShaffrey \& McCafferty, 1988, 1990; Polegatto \& Froehlich, 2001) clearly indicate the feeding habits of these groups.

Most water bugs (Nepomorpha) are carnivorous, including walking (e.g., "water scorpions" Nepidae) and swimming ambush predators (e.g. "giant water bugs" Belostomatidae, "creeping water bugs" Naucoridae and "backswimmers" Notonectidae), aquatic walking (Aphelocheiridae), swimming (occasionally Notonectidae) and secondary terrestrial (Ochteridae and Gelastocoridae) pursuit predators. The water boatmen (Corixoidea) are classi-

\footnotetext{
* Present and corresponding address: Brandenburg State Office of Environment, Tramper Damm 2, 16225 Eberswalde, Germany; e-mail: christian-haedicke@gmx.de
} 
fied as organic scrapers (Hutchinson, 1993; Wetzel, 2001). The mouthparts of Corixoidea are uniquely modified: their rostrum is very short, joined immovably to the head capsule, their fore tarsi ("palae") are modified and there a grinder is situated in their food pump (Parsons, 1965; Martin, 1969; Hädicke, 2012). The morphological specialisation of corixoid mouthparts indicate that these bugs are capable of ingesting and digesting solid food, in contrast with the rest of Hemiptera, which only can consume liquid food.

Hungerford (1948) lists six subfamilies in extant Corixidae: Diaprepocorinae, Micronectinae, Stenocorixinae, Cymatiinae (renamed Cymatiainae due to a homonymy, Štys \& Jansson, 1988), Heterocorixinae and Corixinae. Zimmermann (1986) and Mahner (1993) present the phylogenetic relationships among these taxa. Nieser (2002) raised two of the subfamilies, Diaprepocoridae and Micronectidae, together with the Corixidae (including Cymatiainae), the extinct Shurabellidae and five extinct subfamilies of uncertain affinities and placed them in the superfamily Corixoidea (cf. Popov, 1971, 1986, 1989; Chen et al., 2005; Zhang, 2010). Nieser \& Chen (2006) describe a new subfamily of Micronectidae, Synaptogobiinae and discuss the generic relationships in Micronectidae (cf. Tinerella, 2008). Preliminary results based on molecular and morphological data suggest placing Stenocorixinae and Heterocorixinae in Corixidae (Damgaard et al., unpubl. data).

Ecological preferences of the 600 described species of Corixoidea worldwide (Polhemus \& Polhemus, 2008; Table 1) are only known for a few European (Macan, 1938, 1954; Wróblewski, 1980; Bosman, 1982; Tully et al., 1991; Hutchinson, 1993; Wachmann et al., 2006) and North American species (Hungerford, 1919; Dodson, 1975; Applegate \& Kieckhefer, 1977; Kelts, 1979; Lauck, 1979; Hutchinson, 1993). Scudder (1976) and Hutchinson (1993) summarise the information on corixoid species of brackish waters and inland salt lakes and comment on their occasional occurrence in marine habitats. Several species of Corixoidea benefit from their role as pioneer species in quickly colonising new habitats (Bröring \& Niedringhaus, 1988; Savage, 1989; Wollmann, 2000). The information available on the biology of endemic Australian [Diapre- pocoridae; Andersen \& Weir (2004)], African [Stenocorixinae; Poisson \& Jaczewski (1928); Lansbury (1991); Hädicke (2012); Brożek (2013); Brożek \& Zettel (2014)] and South American species [Heterocorixinae; Heckman (2011)] is mostly based on speculation.

Although often neglected, water bugs in general and Corixoidea in particular are of major importance in aquatic ecosystems (Papáček, 2000, 2001). Especially in aquatic habitats that lack fish (e.g. rock pools, mining lakes and heavily acidified lakes), species of Corixoidea are important predators dominating the food webs (Henrikson \& Oscarson 1981; Wollmann 1997, 2000; Wollmann \& Deneke, 2002; Soldán et al., 2012). On the other hand, species of Corixoidea are a significant food compound in fish (Frost \& Macan, 1948). The potential of European Corixoidea as bioindicators of stagnant water has been outlined (Macan, 1938, 1954; Jansson, 1977; Savage, 1994; Hufnagel et al., 1999; Skern et al., 2010). Several studies underpin the potential value of the Nepomorpha as mosquito control agents (Darriet \& Hougard, 1993; Ohba \& Nakasuji, 2006; Saha et al., 2007; Sivagnaname, 2009). DNA-examinations of the gut contents of invertebrate and vertebrate taxa in Kenyan wetlands revealed Nepomorpha being more efficient than amphibians in reducing mosquitoes of human importance (Ohba et al., 2010). The role of Corixoidea as primary consumers is, however, widely unknown. Therefore, reliable information on their role in matter exchange in aquatic habitats is unknown (Wollmann, 1997; Wollmann \& Deneke, 2002). Corixoidea are positively buoyant and frequently visit the water surface to breathe. Due to their relative independence of dissolved oxygen and feeding on the bottom ooze, Corixoidea are probably crucial for the exchange of organic matter between hypo- and epilimnion, especially during summer stagnation.

In contrast with their frequently high abundance, the bionomics of Corixoidea remain insufficiently known and data on their diet frequently unclear. In the early twentieth century, observations were interpreted in favour of them being herbivores (Hungerford, 1917, 1919). Subsequent studies, however, indicate carnivorous tendencies (e.g. Jansson, 1969; Jansson \& Scudder, 1972). The food source

Table 1. Diversity of water boatmen recorded in different zoogeographical regions, with number of described species and quantity of information on the diet of individual taxa. Information on the diet of Corixoidea is mainly based on Old World species. However, with the exception of the Diaprepocoridae and Cymatiainae (Corixidae), information is available for less than half of the known species. In particular, information on the diet of Neotropical species is limited.

\begin{tabular}{|c|c|c|c|c|}
\hline & & Region & No. of species & Data on diet \\
\hline \multirow{2}{*}{\multicolumn{2}{|c|}{ Diaprepocoridae }} & Australia & 3 species & for 1 species \\
\hline & & New Zealand & 1 species & \\
\hline \multirow{3}{*}{ Micronectidae } & \multirow{2}{*}{ Micronectinae } & Old World & $>100$ species & for 4 species \\
\hline & & New World & 27 species & \\
\hline & Synaptogobiinae & Brazil & 2 species & \\
\hline \multirow{8}{*}{ Corixidae } & Stenocorixinae & Africa & 1 species & \\
\hline & \multirow{3}{*}{ Cymatiainae } & North America & 1 species & \\
\hline & & Eurasia & 4 species & for 3 species \\
\hline & & Oceania & 1 species & \\
\hline & Heterocorixinae & Neotropis & 26-34 species & \\
\hline & \multirow{3}{*}{ Corixinae } & Old World & ca. 200 species & for 34 species \\
\hline & & North America & ca. 120 species & for 11 species \\
\hline & & Neotropis & ca. 122 species & for 5 species \\
\hline
\end{tabular}




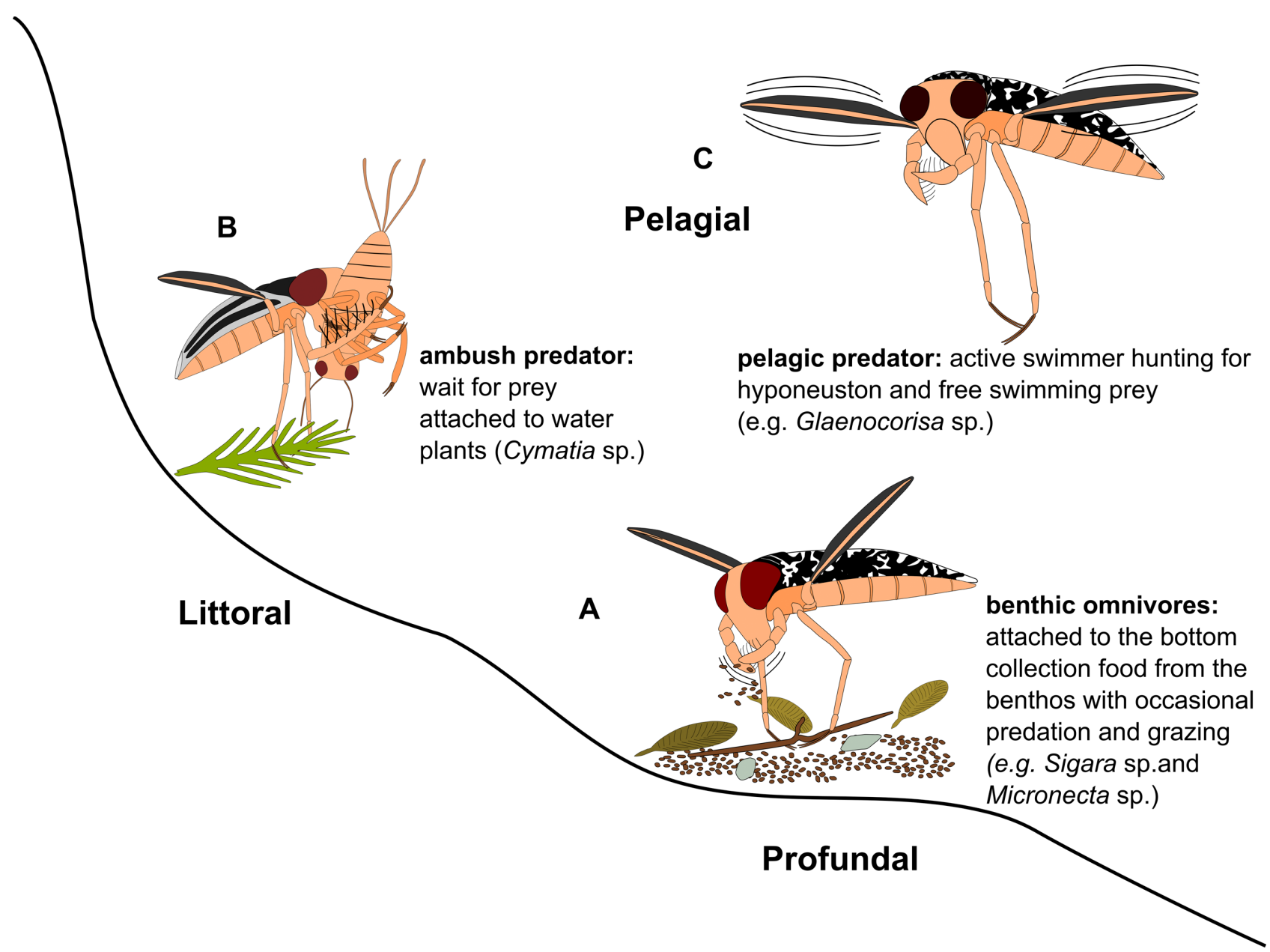

Fig. 1. Schematic drawing of different feeding behaviours of European Corixoidea. Due to their plastron Corixoidea have a positive buoyancy, thus they need to be attached to objects under water. A - most Corixidae and Micronectidae rest attached to the bottom and search for food in the bottom ooze (detritus, algae and small benthic animals) or graze on periphyton. B - species of Cymatia have distinct predatory tendencies, involving certain morphological adaptations (i.e. modified fore tarsi ("palae"), rather globular compound eyes). Often they rest attached to water plants in the littoral from which they ambush passing prey (e.g. ephemerid larvae). C - some species of the subfamily Corixinae (e.g. Glaenocorisa sp. and Graptocorixa sp.) also have more globular compound eyes than the majority of Corixoidea, and pursue prey in the pelagial and below the water surface.

of Corixoidea has been studied for more than a century but is still uncertain. Different methods seem to prove, at least partially, a carnivorous diet, but according to Baptist (1942) Corixa punctata only produces the gut enzymes invertase and amylase. Digestion of animal food is not possible with these enzymes and there are no indications that they have symbiotic bacteria. Although these results have not yet been confirmed by more advanced techniques, they question carnivory in Corixoidea. Surprisingly, the predatory Belostomatidae also produce amylase in their salivary glands (Swart et al., 2006), which is said to digest plant matter in the gut of these predators prey. Although well known in terrestrial insects (reviewed by Terra \& Ferreira, 1994), information on digestion enzymes in aquatic insects is sparse [except for aquatic Heteroptera, Trichoptera (Martin et al., 1981; Bärlocher \& Porter, 1986) and Plecoptera (López-Rodríguez et al., 2012)]. Insights from digestion physiology not only complement traditional gut analyses (López-Rodríguez et al., 2012), but are a useful tool for critically evaluating data on feeding habits in aquatic insects.
When studying data on feeding habits it should always be remembered that observations of an organism handling prey do not indicate consumption, and even the presence of food residues in the alimentary tract detected by microscopic examination or serological or DNA-based methods (i.e. PCR) also does not necessarily prove that either. Representatives of Potamanthidae (Ephemeroptera), for instance, were traditionally placed in the functional group collectors/gatherers, but McCafferty \& Bae (1992) proved they are filter feeders; the presence of particles of chironomid larvae in the gut of Potamanthus luteus are considered to be a result of accidental ingestion (Fenoglio et al., 2008). In addition, not all the nutrients found by advanced techniques are digested; for example, in grasshoppers (Acrididae) only monosaccharides and proteins in the alimentary canal are assimilated, while polysaccharides are not (Beier, 1972). A single method is therefore frequently insufficient for assigning a certain group to a particular functional feeding group (Palmer et al., 1993a; Tomanova et al., 2006).

Feeding habits of Corixoidea attracted much attention in the past century. The present paper summarises and criti- 
cally evaluates data in the literature on the feeding behaviour and feeding habits of this superfamily globally, with the aim of improving our understanding of their ecological significance. In addition, we explore the difficulties in evaluating data on feeding habits in this insect group and invertebrates in general.

\section{FEEDING BEHAVIOUR OF CORIXOIDEA}

Walton (1938) described the feeding behaviour of $M i$ cronecta sp. as follows: "Leaning forward, the Micronecta diligently turns over the bottom refuse, seeking for minute plants and animals; with its palae it holds these against its mouth. Filaments of algae are moved along with a handoverhand motion while the contents of the cells are sucked out. Small pieces of alga may be swallowed whole and can be found in a lacerated condition in the stomach" (Fig. 1A). Based on laboratory observations, Micronecta species do not suck filamentous algae, but manipulate small grains of sand and plant particles using their palae (Wróblewski, 1958). This behaviour suggests that they scrape a biofilm consisting of periphytic algae and other organisms from the surface of the particles, including sessile protozoans and Rotifera. The palae of Neotropical Synaptogobiinae, however, show distinct morphological differences to those of other Micronectidae (Nieser \& Chen, 2006), which probably indicates different feeding habits.

Specimens of Cymatia spp. rest attached to underwater vegetation waiting for prey (Walton, 1943; Lansbury, 1965; Henrikson \& Oscarson, 1985) (Fig. 1B). Accordingly, they and other species of Cymatiainae are usually considered to be exclusively carnivorous, however observations of them with prey are rare (Bakonyi, 1978; Popham et al., 1984).

Different feeding behaviours of European species are summarised by Sutton (1951) and Popham et al. (1984). Most species throw up the bottom ooze and feed on detritus, animals and algae by alternating movements of their palae (Hungerford, 1919). Detritus in the suspended bottom ooze is moved to the mouth and ingested by movements in the cibarium. Algal filaments and active animals are impaled on the stylets and held by both palae above the functional mouth orifice; partly digested food is sucked into the food canal (Fig. 1A). The palae may also sweep over stones, dead animals etc., and detach material that is sucked into the food canal (Buchanan White, 1873). Corixini may occasionally also catch prey with their palae (Popham et al., 1984).

The pelagic species Glaenocorisa propinqua (Glaenocorisini) and Arctocorisa germari (Corixini) are active swimming predators. Both capture prey at the water surface and in mid-water (Walton, 1943; Henrikson \& Oscarson, 1985; Nyman et al., 1985) (Fig. 1C).

\section{DIET OF THE CORIXOIDEA}

No information is available for the feeding habits of some genera of Micronectidae, Stenocorixinae and Heterocorixinae.

\section{Diaprepocoridae}

Diaprepocoris are considered to be carnivorous (Papáček, 2001). An examination of the gut contents of D. zealandiae, however, revealed remains of diatoms and conjugales algae (Hädicke, 2010).

\section{Micronectidae}

Information is only available for species of Micronecta, while the feeding habits of Synaptogobia (Micronectidae: Synaptogobiinae), Monogobia, Tenagobia, and Synaptonecta (Micronectidae: Micronectinae) are unknown.

Published information on the diet of Micronecta is controversial. In early reports, $M$. ovivora is described handling and presumably feeding on fish eggs in India (Westwood, 1871), however, no individual was actually seen to suck an egg (Hutchinson, 1993). Wróblewski (1960) suggests that they feed on detritus and microorganisms. Micronecta spp., unlike Corixidae, do not feed on freezer-preserved or freshly killed aquatic invertebrates in captivity. Providing fresh bottom material from their actual habitats 2-3 times a week successfully kept them alive (Jansson, 1986). Micronecta quadristrigata and some Malayan species of $M i$ cronecta are reported to feed on algae (Fernando \& Leong, 1963). Li \& Zou (2005) report M. sahlbergi consuming detritus and the filamentous alga Ulothrix sp.

In contrast, $M$. grisea is menioned capturing and feeding on insect larvae, including mosquito larvae (Diptera: $\mathrm{Cu}$ licidae). The predation of $3^{\text {rd }}$ instar larvae of the mosquito Stegomyia aegypti by $M$. grisea is confirmed by laboratory experiments (Amrapala et al., 2009). A DNA-analysis of the gut contents of Micronecta spp. from Vietnam and Kenya using PCR also provides evidence for the consumption of mosquito larvae (Aedes, Anopheles) (Ohba et al., 2010, 2011).

\section{Corixidae: Cymatiainae}

Hussey (1921) describes the Nearctic Cymatia americana capturing and feeding on larvae of Chaoborus sp. (Diptera: Chaoboridae) and possibly a crustacean. Cymatia bonsdorffii is considered to be an ambush predator, feeding on various small arthropods, crustaceans (Cyclops sp., Daphnia pulex, Sida crystallina), insect larvae (Ephemeroptera; Heteroptera: Corixidae; Diptera: Chironomidae, $\mathrm{Cu}-$ licidae, Chaboridae; Coleoptera: Haliplidae) and Tubifex sp. (Walton, 1943). Jansson \& Scudder (1972) state that Cymatia sp. capture mosquito larvae. Serological analyses of gut contents of $C$. americana indicate (in decreasing amounts) the presence of chironomids, zygopterans, daphniids, diaptomids and amphipods (Reynolds, 1975). Reilly \& McCarthy (1990) analysed the gut contents of $C$. bonsdorffii and found mainly Diptera larvae (91.4\%, especially Chironomidae) and to a lesser extent cladocerans, copepods and mayfly larvae. Popham et al. (1984) consider C. coleoptrata to be carnivorous based on a visual analysis of its gut contents. Cymatia rogenhoferi is recorded preying on fish eggs, and fry of the common carp, Cyprinus carpio, and the silver carp, Hypophthalmichthys molitrix by Sokol'skaya \& Zhiteneva (1973). 
In contrast, Wachmann et al. (2006) consider C. coleoptrata to be both carnivorous and herbivorous. A study of another species, the Asian C. apparens, based on a microscopic examinations of gut contents, revealed a mixed diet, containing algae, plant matter and dead fish (Li \& Zou, 2005).

\section{Corixidae: Corixinae: Agraptocorixini}

Hale (1924) states that Agraptocorixa eurynome feeds on mosquitoes in captivity. Information on A. hyalinipennis is contradictory. Although there are reports of adults feeding on a diet of boiled potatoes (Quadri, 1951), larvae of this species do not survive if fed algae (Fernando \& Leong, 1963).

\section{Corixidae: Corixinae: Corixini}

There are claims that the diet of Corixini range from detritivory and herbivory to carnivory. Apart from these, Kirby (1983) describes a case of fungivory. Early observations indicate predation on freshwater crustaceans (e.g. Abbott, 1912). Hale (1922) kept several Australian species of Corixinae in aquaria for months, and during that time they were fed only with larvae of the mosquitoes Culex quinquefasciatus $(=C$. fatigans) and Scutomyia notoscripta. Even newly-hatched Corixinae can capture tiny mosquito larvae and increasingly larger individuals were taken during the successive stages of metamorphosis.

In contrast to these carnivorous tendencies, there are many observations on Corixini feeding on detritus and plant matter. First evidence was provided by Hungerford (1917), who observed different Corixini larvae and adults consuming detritus from bottom ooze or dead leaves, consisting of tiny bits of organic matter, diatoms, desmids, Oscillatoria, sometimes veins of leaves, more often dead filaments of Zygnema, unicellular Euglena, Paramecium, Chlamydomonas, spores of various algae, and cysts of $E u$ glena and other unicellular "plants" and "animals". The subsequent examination of their digestive tract revealed filaments of the cyanobacteria (Oscillatoria) 9-10 mm long, and bits of Zygnema filaments consisting of as many as seven cells. However, an attack on a blood worm by a starved Corixini is also recorded. In laboratory experiments, different species of Corixini were provided with different foods in aquaria and subsequently their fore guts were examined. This revealed remnants of various algae (e.g. Ankistrodesmus, Gonatozygon, Mougeotia, Tetraspora, Zygnema), desmids, diatoms, blue-green algae (Oscillatoria), oligochaetes, nematodes, rotifers and protozoa. He also reports corixines piercing the cells of filamentous Spirogyra and sucking out their contents and mentions predation on chironomid larvae. However, Hungerford (1919) did not provide any evidence that they could successfully complete their life cycle on any of these diets.

Examination of the midgut contents of different European Corixini supplied with various foods indicate a distinct preference for general detritus and algal filaments (Sutton, 1951). The species were also provided with different animals, involving chironomid and tanypodid larvae, tanypodid pupae, may fly larvae and Tubifex were offered. Ad- dtionally, corixines were observed feeding on daphniids, Asellus (Crustacea: Isopoda) and other corixines present in pond water placed in the aquaria. Third to $5^{\text {th }}$ instar larvae and adults fed upon all these animals, but first and second instar larvae were only observed feeding on small daphniids. Corixinae frequently feed on their dead or moribund fellows. The results of examinations of the midgut contents of corixine feeding upon detritus are as follows: Corixa punctata: brown and green granular masses, remains of rotifers, Cyclops, algal filaments and protozoa; Corixa panzeri: brown and green granular masses, amoebae, flagellates, ciliates, nematode eggs and bacteria; Sigara striata: thin algal filaments, intact filaments and remains of Anabaena and allied algae, remains of Scendesmus, diatoms, desmids, Cyclops and one pollen grain of Pinus sp.; Sigara falleni: $90 \%$ brown and/or green granular masses, $10 \%$ consisting of algal filaments (cells from full and normal to completely empty; predominantly Spirogyra spp.), setae of oligochaetes (e.g. Tubifex), remains of crustacean appendages, nematocysts of Hydra, diatoms (e.g. Navicula), desmids, cysts of plants, animals and protozoa (e.g. Euglena). Zwart (1965) determined the survival of Corixinae offered different food sources: Tubifex, daphnids, chironomid larvae, dead fresh water animals, water plants, living or decaying algae, natural or laboratory made detritus and in a control without any food, in the laboratory. Corixa punctata, Sigara distincta, and Arctocorisa germari fed on algae, water plants and detritus usually with similar high levels of mortality. Both adults and larvae exhibit higher survival rates when fed animal food. Reynolds (1975) examined the feeding habits of Cenocorixa bifida and C. expleta consumed crustaceans (Diaptomus, Ceriodaphnia, Daphnia), chironomid larvae and zygopteran larvae (Enallagma), juvenile and adult Hesperocorixa laevigata accepted dead and living chironomids, amphipods and zygopterans. In addition, a serological analysis (C. bifida, C. expleta, $H$. laevigata, Callicorixa audeni, Sigara spp.) records frequent reactions with chironomid and zygopteran, followed by ephemeropteran, chaoborid, diaptomid, daphniid and amphipod antiserums; the fewest reactions were detected with pulmonate (only in Cenocorixa spp.) and plant antisera (blue-green algae, Cladophora, macrophytes only in C. bifida). Popham et al. (1984) visually examined the gut contents in 21 species of Corixinae collected in the field. They found considerable variability among the species but with a preference for a mixed diet; only Corixa dentipes and $C$. panzeri seemed to be exclusively carnivorous, and Sigara lateralis, S. limitata, and S. stagnalis exclusively detritivorous. In $S$. falleni, the sexes had different feeding habits: high prevalence of an algal component in males and of a mixture of foods in females.

In summary, most Corixinae consume a mixture of different foods with distinct preferences for either plant or animal food. Variation in food preferences is not only evident between species, but also between sexes (e.g. S. falleni) and developmental stages. A reliable evaluation of the feeding habits of individual species requires detailed studies on their autecology [e.g. Cenocorixa spp., Reynolds \& 
Scudder (1987a, b)]. Additional information on the diet of individual species of Corixinae is given below.

\section{Corixidae: Corixinae: Corixini: Corixa}

Capture of culicid and chironomid larvae is described for Corixa (Poisson, 1935) and of chironomid larvae by C. panzeri (Sutton, 1945). Corixa punctata, collected in a detritus-rich pond, was kept and survived in an aquarium containing only a layer of bottom ooze. The first two instars were observed to feed on Spirogyra by Benwitz (1957). Jaczewski (1961) describe C. punctata attacking and sucking out the larvae of Chironomidae and mayflies (Ephemeroptera).

\section{Corixidae: Corixinae: Corixini: Cenocorixa}

Scudder (1966) successfully reared Cenocorixa bifida (first instar to adult) and C. expleta (the first three larval instars) on a diet of young brine shrimps (Artemia salina, Artemiidae). Scudder (1969a, b) found that $C$. bifida hungerfordi and C. expleta fed almost exclusively on planktonic diaptomids (Diaptomus nevadensis, D. sicilis) in saline lakes in British Columbia. Other species of Cenocorixa and members of other genera of Corixini were successfully reared through several generations on frozen brine shrimp (Jansson \& Scudder, 1972). Feeding niches of C. bifida and C. expleta were studied by Reynolds \& Scudder (1987a, b). Both species feed on living as well as dead prey, most often on larval chironomids, but also on larvae of beetles, chaoborids, ephemeropterans and zygopterans, larval corixines and eggs, amphipods, fairy shrimps, daphniids and diaptomids. Only adults of both species were observed feeding on aquatic angiosperms. All serological reactions with angiosperm antibody were negative, serological reactions to algal antibodies were positive but weak. The authors therefore conclude that the evidence for feeding on algal or angiosperm material is slight and past reports of corixines feeding on aquatic plants may have been just probing for potential prey. In both species, no significant differences were found in relation to age, sex, location, or season, but there are some differences in feeding habits between the larvae and adults in both species, e.g. in their preference for living or dead prey (Reynolds \& Scudder, 1987a,b).

\section{Corixidae: Corixinae: Corixini: Sigara}

Most of the information on the diet of Corixini is based on this genus alone. A considerable variation occurs not only between different Sigara species but also between the sexes (Popham et al., 1984).

Somewhat isolated is an observation of fungivory. Kirby (1983) observed captive individuals of Sigara dorsalis moving their palae rapidly over the surface of dead bodies of other water boatmen covered with a growth of fungal hyphae. Subsequent dissection revealed broken hyphal fragments in the crops of four out of twelve the specimens examined. The hyphae were probably not the primary target of the bugs as there was a large population of ciliate protozoans among the hyphae.

Sigara lateralis is reported feeding on Daphnia pulex in an aquarium (Walton, 1943). Jaczewski (1961) reports ob- serving $S$. falleni sucking out mayfly larvae (Cloeon spp.). In some Sigara species, interspecific predation regulates population densities. Sigara scotti attacks and sucks 2\% and $S$. dorsalis up to $40 \%$ of their own eggs in laboratory cultures (Young, 1965). Species of Sigara can cause significant harm to fish populations (Sokol'skaya \& Zhiteneva, 1973). Despite the presence of Potamogeton and filamentous algae in the aquarium, adults and larvae of $S$. lateralis and $S$. striata prefer larvae (younger than 10 days) of $C y$ prinus carpio and Hypophthalmichthys molitrix. In S. falleni, these authors did not always detect predation on juvenile fish, but the consumption of the Daphnia added to the experimental cages. In some experiments 6-day old larvae of $H$. molitrix were killed by females of $S$. falleni in whose oviducts mature eggs were found. All three species examined consumed fish eggs in large numbers (Sokol'skaya \& Zhiteneva, 1973). Gut examinations of three species of Sigara (S. falleni, S. lateralis, and S. striata) revealed animal body fluid (S. striata $95.3 \%$, S. falleni $89.5 \%$, S. lateralis 61.0-99.3\%); small amount of algae (S. striata $4.5 \%$, S. falleni $10.25 \%$, S. lateralis $0.3-38.5 \%$ ) and negligible amounts of detritus (Bakonyi, 1978). However, seasonal variation in the ratio of the animal and algal component is recorded in S. lateralis. Feeding experiments by Henrikson \& Oscarson (1981) and Nyman et al. (1985) reveal that S. distincta, and S. scotti are predators of Cladocera, Copepoda and Chaoborus.

More recently, Alahmed et al. (2009) studied predation of $S$. hoggarica on larvae and pupae of the mosquito Culex quinquefasciatus, both in an aquarium and in the field. The results show that the predatory efficiency of $S$. hoggarica was highest when attacking first instar larvae and decreases as the size and age of the prey increases. In experiments on foraging efficiency, Klečka (2014) shows that $S$. striata prefers feeding on zooplankton, in particular chironomid midges and significantly less so on Culex sp., Cloeon sp. and Daphnia sp. Sigara alternata fed on frozen brine shrimps do not reproduce, but do so after a week on a diet of freshly killed mayfly larvae (Jansson \& Scudder, 1972). This example may indicate that the nutritional value of different animals differ in terms of being suitable for reproduction.

Quadri (1951) kept specimens of $S$. promontoria alive for several weeks on boiled potatoes mixed with water, suggesting herbivory in this species.

Based on laboratory feeding experiments with S. striata involving detritus, plants (algae belonging to the genera Zygnema, Cladophora, Rhizoclonium and apical parts of Ceratophyllum and Myriophyllum leaves) and animal food (Tubifex, planktonic crustaceans, chironomid larvae), Puchkova (1969) proposes that this species has a mixed diet based on herbivory, with optional consumption of animal food; however, if plant food is not available, it can survive on animal food. A mixed diet of algae, plants, detritus and dead fish is also reported for S. bellula (Li \& Zou, 2005).

\section{Corixidae: Corixinae: Corixini: Trichocorixa}

According to Sailor (1948), all species of Trichocorixa feed on flocculent bottom ooze, diatoms and algae. This 
author frequently observed both $T$. calva and $T$. kanza feeding on Spirogyra, thrusting its stylets into each cell, and sucking out the contents. Carnivory is indicated for some species of Trichocorixa, which were observed to seize their own eggs, pierce them with their stylets and suck them dry. A serological analysis of the gut contents of $T$. verticalis interiores revealed Chironomidae are the main food source (Scudder, 1976). Trichocorixa verticalis sellaris preys on certain animals (Chironomus, Ceratopogonidae and Oligochaeta) and on detritus and algae (Kelts, 1979). Trichocorixa verticalis is described as a predator of the brine shrimp species Artemia franciscana in Great Salt Lake (Utah) by Wurtsbaugh (1992). These result were confirmed in a microcosm experiment.

\section{Corixidae: Corixinae: Corixini: Callicorixa and Arctocorisa}

Sailor \& Lienk (1954) observed predatory behaviour in males and females of Callicorixa audeni and C. alaskensis kept in jars and conclude that they are important in limiting the abundance of the mosquito Aedes communis.

Arctocorisa germari survives if supplied with Microspora sp., chironomid larvae and Lumbriculus variegatus (Crisp, 1961). James (1966) observed C. audeni feeding on mosquito larvae. Rock pool Corixini, Arctocorisa carinata and $C$. producta principally attack chironomid larvae and other bottom-living animals (Pajunen, 1970). In the laboratory, they also attack planktonic Crustacea and culicid larvae. Females of both species also tend to suck their eggs (causing losses of 20-50\%) when in pools in which the population density is high and food is scarce (Pajunen, 1970; Pajunen \& Pajunen, 1991). Cannibalism and interspecific predation is recorded in both $A$. carinata and $C$. producta (Pajunen, 1970, 1979a, b; Pajunen \& Ukkonen, 1987; Ranta \& Espo, 1989; Pajunen \& Salmi, 1991; Pajunen \& Pajunen, 1992, 1993). The prey-capture efficiency of cladocerans (Daphnia) and chironomid larvae by A. carinata and $C$. producta depends on the depth of the water and these Corixini prefer different types and sizes of prey depending on their developmental stage (Ranta \& Espo, 1989). Pajunen (1990) successfully used frozen Chironomus larvae to rear A. carinata and C. producta in a field experiment.

\section{Corixidae: Corixinae: Corixini: Hesperocorixa}

Jaczewski (1961) mentions Hesperocorixa linnaei sucking out mayfly, chironomid and culicid larvae and filamentous algae. While some European species of the genera Arctocorisa, Callicorixa and Sigara feed on enchytraeids, those of Hesperocorixa refuse enchytraeids in captivity and feed on algae growing on the walls of the aquarium (Jansson, 1969).

\section{Corixidae: Corixinae: Corixini: Ramphocorixa}

Abbott (1912) reports several old larvae of Ramphocorixa acuminiata feeding on ostracods. Detailed studies of the feeding habits of $R$. acuminata by Griffith (1945) under natural and laboratory conditions indicate mixed feeding on protozoans (Lepocinclis, Pleodorina, Trichoda,
Phacus, Amoeba, Coleps, Paramecium) and tiny animals (nematodes and rotifers, tadpoles), algae and blue-green algae (Oscillatoria, Anabaena, Merismopedia, Pleurococcus, Achnathidium, Navicula, Amphora, Pleurosigma and Cosmarium).

\section{Corixidae: Corixinae: Corixini: Trichocorixella}

$1^{\text {st }}$ and $2^{\text {nd }}$ instar larvae of Trichocorixella mexicana develop well on autoclaved mud and algae, but third to fifth instar larvae of the same species require an additional nutritional source in the form of Tubifex worms if they are to complete their development (Peters \& Ulbrich, 1973).

\section{Corixidae: Corixinae: Glaenocorisini}

Glaenocorisa cavifron is reported feeding on Daphnia pulex in an aquarium (Walton, 1943). Jansson \& Scudder (1972) reared Glaenocorisa sp. on a diet of mosquito larvae. Nyman et al. (1985) describe G. propinqua as a predator of Cladocera, Copepoda and Chaoborus. Hrdličková (2014) analysed the gut contents of G. propinqua in three different acidified, fish-less lakes in the Bohemian Forest Mts and compared these results with the zooplanktonic community. Different planktonic crustaceans (Copepoda and Cladocera) were identified as the main food source, but there were remarkable differences in the relative representation of planktonic crustaceans in food of different populations of $G$. propinqua in the lakes studied. In one lake, Hrdličková (2014) found a large amount of algae in the gut of $G$. propinqua and suggests that these algae were ingested while feeding on herbivorous crustaceans.

\section{FEEDING HABITS IN CORIXOIDEA AND THEIR ASSIGNMENT TO FUNCTIONAL FEEDING GROUPS}

As demonstrated by this review, in spite of more than a century of research, the diet of Corixoidea has remained uncertain. The only two groups for which relevant information is available are the Cymatiainae and Corixini. Cymatiainae seem to be almost exclusively predators, whose hunting strategy includes waiting while perched on vertical surfaces (usually macrophytes), followed by quick attack and prey capture (e.g. Walton, 1943). Species of Cymatiainae are thus considered to be predators. Indications of herbivorous tendencies (Li \& Zou, 2005; Wachmann et al., 2006), however, need to be confirmed.

On the other hand, the diet of Corixini and Glaenocorisini is less clear and the evidence is often contradictory. For example, the European Sigara lateralis is recorded as either exclusively detritivorous (Popham et al., 1984), omnivorous but overwhelmingly zoophagous (Bakonyi, 1978), or mainly preying on juvenile fish (Sokol'skaya \& Zhiteneva, 1973). Considering the flaws in the various methods used (see below), a carnivorous diet is well documented for Corixini, first of all by successfully rearing on such a diet (e.g. Jansson, 1969; Jansson \& Scudder, 1972) and numerous observations of corixines attacking and consuming various invertebrates and fish larvae, including corixine eggs and their own nymphs (for references see above). However, there is also some evidence of them consuming algae, such as observations of them sucking out 
Spirogyra cells (Hungerford, 1919) and a minor but positive reaction in serological studies (Reynolds \& Scudder, 1987b). The consumption of detritus seems to be the least convincing feeding strategy as it usually concerns animals kept under artificial conditions and is probably a result of starvation, or the consumption of detritus might be merely accidental during feeding on detritus-living protozoans, rotifers and nematodes, exactly the opposite to what Hungerford (1948) suggests, who considers the presence of small animals in guts of Corixini to be a result of accidental consumption during feeding on detritus. The fact that neither herbivory nor detritivory could be the main feeding strategy of Corixini seems to be supported by the lack of any successful breeding experiments using such diets.

Another factor complicating the determination of the diet of Corixini might be the variability in the nature of the food consumed by the different stages, sexes and in different seasons, as suggested by some of the investigations (Bakonyi, 1978; Popham et al., 1984; Reynolds \& Scudder, 1987a). Based on the available information, species of Corixini could be either carnivorous or omnivorous with an animal component in their food. With the exception of the Glaenocorisini, which are predators, it is currently not possible to place Corixinae into a specific functional feeding group. There are uncertainties about the digestive enzymes in this group (Baptist, 1942) and the differences in the feeding habits of the sexes [S. falleni; Popham et al., (1984)] and different developmental stages (Reynolds \& Scudder, 1987a, b). It is, however, obvious that regarding all Corixoidea as gatherer-collectors does not reflect the diversity of feeding habits in this group.

Agraptocorixini seem to be predators; the food of Synaptogobiinae, Stenocorixinae and Heterocorixinae is unknown; while that of Diaprepocoridae and Micronectinae is mostly a matter of speculation. The experience of Jansson (1986) that European Micronecta (body length $<2 \mathrm{~mm}$ ) may be kept in aquarium and only provided with fresh bottom material from their habitats indicates where to search for the microscopic prey of these animals. Also the observation of Wróblewski (1958) of European species of Micronecta handling small grains of sand and plant particles indicates they may scrape the biofilm of periphytic algae, bacteria and other organisms from the surface these particles. The first good evidence for consumption of mosquito larvae by tropical Micronecta spp. (body length usually 2-4 mm), obtained using PCR analysis of their gut contents, has recently been published (Ohba et al., 2010, $2011)$; it is also is in accordance with laboratory observations (Amrapala et al., 2009). However, observations of Micronecta consuming algae and detritus also exist (Fernando \& Leong, 1963; Li \& Zou, 2005). Thus, placing one of these species in a certain functional feeding group is premature.

It is evident that Corixoidea have a diverse range of feeding strategies, with different species being assigned to different functional feeding groups (Table 2). The limited information on the biology and ecology of Diaprepocoridae, Micronectidae and some Corixidae (e.g., Stenocorixinae and Heterocorixinae), however, greatly hampers the definitive placement in a particular functional feeding group.

\section{IMPLICATIONS FOR PLACING AQUATIC INSECTS IN FUNCTIONAL FEEDING GROUPS}

Controversial information is partly due to the different methods used to analyse the diet of certain species, some of them being less informative than others (Table 3). Macroscopic observations can give a first hint, but alone can only result in mere speculation [e.g. feeding on fungal hyphae reported by Kirby (1983)]. Hypotheses based on such observations can be tested against specific morphological and behavioural adaptations [e.g. fore feet and grinder in Corixoidea (Parsons, 1965; Martin, 1969; Popham et al., 1984; Hädicke, 2012), Ephemeroptera and Trichoptera (Wallace \& Merritt, 1980; Merritt \& Wallace; 1981; Palmer et al., 1993b; Elpers \& Tomka, 1994; Polegatto \& Froehlich, 2001) and other aquatic insects (Wichard et al., 2013)].

Simple microscopic observations of the gut contents (e.g. colour of the gut contents) may also be misleading and certainly less reliable than specific serological methods (Reynolds \& Scudder, 1987b). Gut fluorescence (Cowan \& Peckarsky, 1990) is a powerful tool for quantitative studies on functional feeding groups only if a diet of algae is already indicated (Glozier et al., 2000). Most recent advances in studies on animal diets have used DNA-analysis (e.g. Valentini et al., 2009).

While these methods are suitable for demonstrating the range of the diet, they do not indicate that such a diet is sufficient for completion of the whole developmental cycle. For Periplaneta americana (Blattodea: Blattidae), Bignell (1982) points out that: "Essential nutrients are those required for indefinite growth and reproduction ...". Successful laboratory breeding experiments in which animals are provided with a single type of food ad libitum do not exclude the possibility of a more variable diet under natural conditions. An insufficient supply of nutrients under laboratory and natural condition is maybe enough to keep an organism alive but does not guarantee successful reproduction and thereby the survival of the population.

Table 2. Assignment of different Corixoidea to functional feeding groups. Information on the gut contents and behaviour of Diaprepocoridae, Micronectidae and some Corixidae indicates assignment to the guild Scrapers/grazers, whether it is a general feeding habit needs further study. Representatives of Corixini are the only unambiguous example of gatherer-collectors, the functional morphology of other Corixoidea taxa also indicates an assignment to this guild. Available information on the diet, behaviour, functional morphology and breeding of Cymatiainae justify an assignment to the predator guild.

\begin{tabular}{lc}
\hline Functional feeding group & Corixoidea taxa \\
\hline Scrapers/grazers & $\begin{array}{c}\text { probably Diaprepocoridae, } \\
\text { Micronectidae?, some Corixidae }\end{array}$ \\
\hline Gatherer-collectors & $\begin{array}{c}\text { Corixini, Agraptocorixini?, } \\
\text { Heterocorixinae?, Stenocorixinae,? } \\
\text { Micronectidae? }\end{array}$ \\
\hline Predators & $\begin{array}{c}\text { Cymatiainae, some Corixini, } \\
\text { Glaenocorisini, Stenocorixinae?, some } \\
\text { Heterocorixinae?, larval Agraptocorixini? }\end{array}$ \\
\hline
\end{tabular}


Table 3. Correlation between different sources of information and their reliability. Reliability increases from mere observations to successful breeding. Every attempt to clarify feeding habits has its limitations. Thus, using a combination of different methods is more likely to result in reliable conclusions.

\begin{tabular}{|c|c|c|}
\hline & Source of information & Limitations \\
\hline 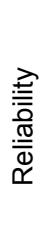 & $\begin{array}{l}\text { observations on behaviour in nature and captivity } \\
\text { functional morphology/morphological adaptations } \\
\text { microscopic examinations of gut contents } \\
\text { serological and DNA-based examinations of gut contents } \\
\text { successful breeding experiments using specific diets }\end{array}$ & $\begin{array}{l}\text { a reliable differentiation between probing and feeding is difficult } \\
\text { only useful if considered in the context of behaviour } \\
\text { fine organic matter impossible to separate, artificial uptake } \\
\text { cannot be excluded } \\
\text { artificial uptake cannot be excluded } \\
\text { influence of other ecological factors (biotic and abiotic) cannot } \\
\text { be excluded }\end{array}$ \\
\hline
\end{tabular}

To improve our knowledge on the alimentation of Corixoidea in particular and aquatic insects in general, analysis of functional morphology, gut contents (serological and/or DNA-based methods) should be used to identify the food consumed under natural conditions (Ohba et al., 2010, 2011; Klimaszewski et al., 2013), with subsequent evaluation of the results and determination of the nutritional value of the food consumed in laboratory breeding experiments.

ACKNOWLEDGEMENTS. We like to express our thanks to the Senckenberg German Entomological Institute, M. Mahner and the Apsoma group for providing rare literature. J. Aldhoun checked our English, and A. Prokin kindly helped us with translation of Russian papers. We also would like to thank P. Štys and two anonymous reviewers for useful comments on the manuscript. CWH is supported by a fellowship of the Landesgraduiertenstiftung Mecklenburg-Vorpommern. The preparation of this manuscript received partial financial support from the Ministry of Culture of the Czech Republic to the National Museum, Prague (DKRVO 2016/14) for PK and the National Natural Science Foundation of China (grant no. 31472024) for DR.

\section{REFERENCES}

Аввотт J.F. 1912: A new type of Corixidae (Ramphocorixa balanodis, n. gen., et sp.) with an account of its life history. - Can. Entomol. 44: 113-121.

Alahmed A.M., Alamr S.A. \& Kheir S.M. 2009: Seasonal activity and predatory efficacy of the water bug Sigara hoggarica Poisson (Hemiptera: Corixidae) against the mosquito larvae Culex quinquefasciatus (Diptera: Culicidae) in Riyadh city. Saudi Arabia. - J. Entomol. 6: 90-95.

Amrapala C., Sitthicharoenchal D., Thavara U., Tawatsin A. \& Chittinusna T. 2009: Feeding ability of Micronecta grisea nymphal instars and adults on third instar Aedes aegypti larvae. - Nat. Hist. J. Chulalongkorn Univ. 9: 189-200.

Andersen N.M. \& WeIR T. 2004: Australian Water bugs (Hemiptera - Heteroptera, Gerromorpha \& Nepomorpha): Their Biology and Identification. Apollo Books, Stenstrup, 334 pp.

Applegate R.L. \& Kieckhefer R.W. 1977: Ecology of Corixidae (water boatmen) in Lake Poinsett, South Dakota. - Am. Midl. Nat. 97: 198-208.

BAKONYI G. 1978: Contribution to the knowledge of the feeding habits of some water boatmen: Sigara spp. (Heteroptera: Corixidae). - Fol. Entomol. Hung. 31: 19-24.

BAPTIST B.A. 1942: The morphology and physiology of the salivary glands of Hemiptera - Heteroptera. - Q. J. Microsc. Sci. 83: 91-139.

BÄrlocher F. \& Porter C.W. 1986: Digestive enzymes and feeding strategies of three stream invertebrates. $-J$. North Am. Benthol. Soc. 5: 58-66.
BEIER M. 1972: Saltatoria (Grillen und Heuschrecken). In Helmkke J.-G., Starck D. \& Wermuth H. (eds): Handbuch der Zoologie 4/2 Arthropoda Insecta. De Gruyter, Berlin, pp. 1-217.

Benwitz G. 1957: Der Kopf von Corixa punctata Ill. (geoffroyi Leach) (Hemiptera - Heteroptera). - Zool. Jb. Abt. Anat. Ontog. Tiere 75: 311-378.

Bignell D.E. 1982: Nutrition and digestion. In Bell W.J. \& Adiyodi K.G. (eds): The American Cockroach. Chapman \& Hall, London, New York, pp. 57-86.

Bosman R. 1982: Distribution and ecology of Belgian Corixidae (Hemiptera). - Acad. Analecta 44: 21-60.

BRörIng U. \& Niedringhaus R. 1988: Die Verbreitung aquatischer und semiaquatischer Heteroptera (Hemiptera: Nepomorpha, Gerromorpha) auf küstennahen Düneninseln der Nordsee. - Abh. Naturwiss. Ver. Bremen 41: 7-16.

BRożeK J. 2013: Deliberations on the external morphology and modification of the labial segments in the Nepomorpha (Heteroptera: Insecta) with notes on the phylogenetic characteristics. - Sci. World J. 2013: 1-49.

BrożeK J. \& Zettel H. 2014: A comparison of the external morphology and functions of labial tip sensilla. - Eur. J. Entomol. 111: 275-297.

Buchanan White F. 1873: Notes on Corixa. - Entomol. Mon. Mag. 10: 75-80.

Chen P.-P., Nieser N. \& Zettel H. 2005: The Aquatic and SemiAquatic Bugs (Heteroptera: Nepomorpha \& Gerromorpha) of Malaysia. - Fauna Malesiana Handbook 5: 546 pp.

Cowan C.A. \& Peckarsky B.L. 1990: Feeding by a lotic mayfly grazer as quantified by gut fluorescences. - J. North Am. Benthol. Soc. 9: 368-378.

CRISP D.T. 1961: A study of egg mortality in Corixa germari Fieb. (Hem., Corixidae). - Entomol. Mon. Mag. 96: 131-132.

Cummins K.W. 1973: Trophic relations of aquatic insects. Annu. Rev. Entomol. 18: 183-206.

Darriet F. \& Hougard J.-M. 1993: Étude en laboratoire de la biologie et capacitiés prédatrices de l'Hétéroptère aquatique $R a$ natra parvipes vicina (Signoret, 1880) à l'encontre des larves de moustiques. - Rev. Hydrobiol. Trop. 26: 305-311.

Dodson V.E. 1975: Life histories of three species of Corixidae (Hemiptera; Heteroptera) from western Colorado. — Am. Midl. Nat. 94: 257-266.

ElPers C. \& Tomka I. 1994: Structure of mouthparts and feeding habits of Potamanthus luteus (Linné) (Ephemeroptera: Potamanthidae). - Arch. Hydrobiol. (Suppl.) 99: 73-96.

Fenoglio S., Bo T., Tierno de Figueroa J.M. \& Cucco M. 2008: Nymphal growth, life cycle, and feeding habits of Potamanthus luteus (Linnaeus, 1767) (Insecta: Ephemeroptera) in the Bormida River, Northwestern Italy. — Zool. Stud. 47: 185-190.

Fernando C.H. \& Leong C.Y. 1963: Miscellaneous notes on the biology of Malayan Corixidae (Hemiptera: Heteroptera) and a study of the life histories of two species, Micronecta quadri- 
strigata Bredd. and Agraptocorixa hyalinipennis (F.). $-J$ Nat. Hist. 69: 545-558.

Frost W.E. \& Macan T.T. 1948: Corixidae (Hemiptera) as food of fish. - J. Anim. Ecol. 17: 174-179.

Glozier N.E., Culp J.M., Scrimgeour G.J. \& Halliwell D.B. 2000: Comparison of gut fluorescence and gut dry mass techniques for determining feeding periodicity in lotic mayflies. J. North Am. Benthol. Soc. 19: 169-175.

GrifFITH M.E. 1945: The environment, life history and structure of the water boatman, Ramphocorixa acuminata (Uhler) (Hemiptera, Corixidae). - Univ. Kans. Sci. Bull. 30: 241-365.

HäDıCKe C.W. 2010: Die Mundwerkzeuge der Corixidae Leach, 1815 (Heteroptera: Nepomorpha) eine phylogenetische Interpretation. Unpubl. Thesis, University of Rostock, 86 pp.

HäDıCKE C.W. 2012: Die Mundwerkzeuge der Corixoidea (Börner, 1935) (Heteroptera: Nepomorpha) und deren Evolution. Mitt. Dtsch. Ges. Allg. Angew. Entomol. 18: 99-106.

Hale H.M. 1922: Studies in Australian aquatic Hemiptera. No. 1. - Rec. South Aust. Mus. 2: 309-330.

Hale H.M. 1924: Studies in Australian aquatic Hemiptera. No. IV. - Trans. R. Soc. S. Aust. 48: 7-9.

Heckman C.W. 2011: Encyclopedia of South American Aquatic Insects: Hemiptera - Heteroptera. Springer, Dordrecht, 680 pp.

Henrikson L. \& Oscarson H. 1981: Corixids (Hemiptera - Heteroptera), the new top predators in acidified lakes. - Verh. Int. Ver. Theor. Angew. Limnol. 21: 1616-1620.

Henrikson L. \& Oscarson H. 1985: Waterbugs (Corixidae, Hemiptera - Heteroptera) in acidified lakes: Habitat selection and adaptations. - Ecol. Bull. 37: 232-238.

HRDLIČKOVÁ J. 2014: [Foraging Strategies of Invertebrate Predators in Mountain Lakes]. Unpubl. Thesis, Charles University, Prague, 67 pp. [in Czech].

Hufnagel L., BaKonyi G. \& VÁsÁrhelyi T. 1999: New approach for habitat characterization based on species lists of aquatic and semiaquatic bugs. - Environ. Monit. Assess. 58: 305-316.

Hungerford H.B. 1917: Food habits of corixids. $-J$. N. Y. Entomol. Soc. 25: 1-5.

Hungerford H.B. 1919: The biology and ecology of aquatic and semiaquatic Hemiptera. - Univ. Kans. Sci. Bull. 11: 1-341.

Hungerford H.B. 1948: The Corixidae of the Western Hemisphere (Hemiptera). — Univ. Kans. Sci. Bull. 32: 1-827.

HuSSEY R.F. 1921: Ecological Notes on Cymatia americana (Corixidae, Hemiptera). - Bull. Brooklyn Entomol. Soc. 16: 131-136.

Hutchinson G.E. 1993: A Treatise on Limnology. Vol. IV. The Zoobenthos. John Wiley \& Sons, New York, 964 pp.

JACZEWSKI T. 1961: Notes on the biology of Corixidae (Heteroptera). - Pol. Pis. Entomol. 31: 295-300.

JAMES H.G. 1966: Insect predators of univoltine mosquitoes in woodland pools of the Pre-Cambrian Shield in Ontario. Can. Entomol. 98: 550-555.

JANSSON A. 1969: Identification of larval Corixidae of Northern Europe. - Ann. Zool. Fenn. 6: 289-312.

Jansson A. 1977: Micronectae (Heteroptera, Corixidae) as indicators of water quality in two lakes in southern Finland. - Ann. Zool. Fenn. 14: 118-124.

JANSSON A. 1986: The Corixidae (Heteroptera) of Europe and some adjacent regions. — Acta Entomol. Fenn. 47: 1-94.

JANSSON A. \& ScUdDER G.G.E. 1972: Corixidae (Hemiptera) as predators: rearing on frozen brine shrimp. - J. Entomol. Soc. Br. Columbia 69: 44-45.

KeLts L.J. 1979: Ecology of a tidal marsh corixid, Trichocorixa verticalis (Insecta, Hemiptera). - Hydrobiologia 64: 37-57.
KIRBY P. 1983: Sigara dorsalis (Leach) (Hem., Corixidae) feeding on fungal hyphae. - Entomol. Mon. Mag. 119: 72.

Klausnitzer B. 1996: Käfer im und am Wasser. Westarp Wissenschaften, Magdeburg, 200 pp.

KLEČKA J. 2014: The role of a water bug, Sigara striata, in freshwater food webs. - Peer J. 2: e389, 16 pp.

Klimaszewski J., Morency M.-J., Labrie P., Séguin A., Langor D., Work T., Bourdon C., Thiffault E., Paré D., Newton A.F. \& THAYER M.K. 2013: Molecular and microscopic analysis of the gut contents of abundant rove beetle species (Coleoptera, Staphylinidae) in the boreal balsam fir forest of Quebec, Canada. - ZooKeys 353: 1-24.

LansBury I. 1965: Notes on the Hemiptera, Coleoptera, Diptera and other invertebrates of the Burren, Co. Clare and Inishmore, Aran Islands. - Proc. R. Ir. Acad. (B) 64: 89-115.

Lansbury I. 1991: Cuticular blades and other structures of Diaprepocoris Kirkaldy and Stenocorixa Horvath (Heteroptera: Corixidae). — Tijdschr. Entomol. 132: 183-198.

LAUCK D.A. 1979: Family Corixidae Water Boatmen. In Menke A.S. (ed.): Semiaquatic and Aquatic Hemiptera of California Heteroptera, Hemiptera. - Bull. Californ. Insect Surv. 21: 87-123.

Li C.-R. \& Zou L.-Z. 2005: A study on the feeding habit of 3 corixids (Hemiptera: Corixidae). - J. Yangtze Univ. Nat. Sci. Ed. 2: 33-34 [in Chinese, English abstr.].

López-Rodríguez M.J., Trenzado C.E., Tierno de Figueroa J.M. \& SANZ A. 2012: Digestive enzyme activity and trophic behavior in two predator aquatic insects (Plecoptera, Perlidae). A comparative study. - Comp. Biochem. Physiol. (A) 162: 31-35.

MACAN T.T. 1938: Evolution of aquatic habitats with special reference to the distribution of Corixidae. - J. Anim. Ecol. 7: $1-19$.

MACAN T.T. 1954: A contribution to the study of the ecology of Corixidae (Hemipt.). - J. Anim. Ecol. 23: 115-141.

MAHNER M. 1993: Systema cryptoceratorum phylogeneticum (Insecta, Heteroptera). - Zoologica 143: 1-302.

Martin N.A. 1969: The Food, Feeding Mechanisms and Ecology of the Corixidae (Hemiptera - Heteroptera), with Special Reference to Leicestershire. Unpubl. PhD Thesis, University of Leicester, $245 \mathrm{pp}$.

Martin M.M., Kukor J.J., Martin J.S., Lawson D.L. \& Merritt R.W. 1981: Digestive enzymes of larvae of three species of caddisflies (Trichoptera). - Insect Biochem. 11: 501-505.

MCCAFFERTY W.P. \& BAE Y.J. 1992: Filter-feeding habits of the larvae of Anthopotamus (Ephermeroptera: Potamanthidae). Ann. Limnol. 28: 27-34.

McShaffrey D. \& McCAFFerTy W.P. 1988: Feeding behavior of Rhithrogena pellucida (Ephermeroptera: Heptageniidae). - J. North Am. Benthol. Soc. 7: 87-99.

McShaffrey D. \& McCAFFerty W.P. 1990: Feeding behavior and related functional morphology of the mayfly Ephemerella needhami (Ephermeroptera: Ephemerellidae). - J. Insect Behav. 3: 673-688.

Merritt R.W. \& Wallace J.B. 1981: Filter-feeding insects. Sci. Am. 244: 132-144.

NIESER N. 2002: Guide to aquatic Heteroptera of Singapore and peninsular Malaysia. IV. Corixoidea. — Raffles Bull. Zool. 50: 263-274.

Nieser N. \& Chen P.-P. 2006: Two new genera and a new subfamily of Micronectidae (Heteroptera, Nepomorpha) from Brazil. In Rabitsch W. (ed.): Hug the bug - For love of true bugs. Festschrift zum 70. Geburtstag von Ernst Heiss. — Denisia 19: 523-534. 
Nyman H.G., Oscarson H. \& Stenson J.A.E. 1985: Impact of invertebrate predators on the Zooplankton composition in acid forest lakes. - Ecol. Bull. 37: 239-243.

OhвA S. \& NAKASUлI F. 2006: Dietary items of predacious aquatic bugs (Nepoidea: Heteroptera) in Japanese wetlands. - Limnology 7: 41-43.

Ohba S., Kawada H., Dida G.O., Juma D., Sonye G., Minakawa N. \& TAKagi M. 2010: Predators of Anopheles gambiae sensu lato (Diptera: Culicidae) larvae in wetlands, Western Kenya: confirmation by polymerase chain reaction method. $-\mathrm{J}$. Med. Entomol. 47: 783-787.

Ohba S., Trang Huynh T.T., Kawada H., Le L.L., Ngoe H.T., Hoang S.L., Higa Y. \& TAKagi M. 2011: Heteropteran insects as mosquito predators in water jars in southern Vietnam. $-J$ Vector Ecol. 36: 170-174.

PaJunen V.I. 1970: Adaptation of Arctocorisa carinata (Sahlb.) and Callicorixa producta (Reut.) populations to a rock pool environment. In: Proc. Adv. Study Inst. Dyn. Numbers Popul. Ooserbeek 1970. pp. 148-158.

PaJunen V.I. 1979a: Competition between rock pool corixids. Ann. Zool. Fenn. 16: 138-143.

PAJUNEN V.I. 1979b: Quantitative analysis of competition between Arctocorisa carinata (Sahlb.) and Callicorixa producta (Reut.) (Hemiptera, Corixidae). - Ann. Zool. Fenn. 16: 195-200.

Pajunen V.I. 1990: The population dynamics of rock-pool corixids living on supplementary food (Hemiptera, Corixidae). Ann. Zool. Fenn. 27: 337-350.

Pajunen V.I. \& Pajunen I. 1991: Oviposition and egg cannibalism in rock-pool corixids (Hemiptera: Corixidae). — Oikos 60: 83-90.

PaJunen V.I. \& Pajunen I. 1992: Field evidence of intra- and interspecific predation in rock-pool corixids (Hemiptera: Corixidae). - Entomol. Fenn. 3: 15-19.

Pajunen V.I. \& PaJunen I. 1993: Competitive interactions limiting the number of species in rock pools: experiments with Sigara nigrolineata. - Oecologia 95: 220-225.

PAJUNEN V.I. \& SALMI J. 1991: The influence of corixids on the bottom fauna of rock-pools. - Hydrobiologia 222: 77-84.

PaJunen V.I. \& UKKonen M. 1987: Intra- and interspecific predation in rock pool corixids. - Ann. Zool. Fenn. 24: 295-304.

Palmer C., O’Keeffe J., Palmer A., Dunne T. \& Radloff S. 1993a: Macroinvertebrate functional feeding groups in the middle and lower reaches of the Buffalo River, Eastern Cape, South Africa. I. Dietary variability. — Freshw. Biol. 29: 442453.

Palmer C., O’Keeffe J. \& Palmer A. 1993b: Macroinvertebrate functional feeding groups in the middle and lower reaches of the Buffalo River, Eastern Cape, South Africa. II. Functional morphology and behaviour. - Freshw. Biol. 29: 455-462.

Palmer C.G., Brenton M., Palmer A.R. \& O'Keeffe J.H. 1996: An assessment of macroinvertebrate functional feeding groups as water quality indicators in the Buffalo River, Eastern Cape Province, South Africa. - Hydrobiologia 318: 153-164.

PAṔČ́̌K M. 2000: Small aquatic bugs (Nepomorpha) with slight or underestimated economic importance. In Schaefer C.W. \& Panizzi A.R. (eds): Heteroptera of Economical Importance. CRC Press, Boca Raton, pp. 591-600.

PAPÁČEK M. 2001: Small aquatic and ripicolous bugs (Heteroptera: Nepomorpha) as predators and prey: The question of economical importance. - Eur. J. Entomol. 98: 1-12.

Parsons M.C. 1965: Modifications of the food pumps of Hydrocorisae (Heteroptera). - Can. J. Zool. 44: 585-620.

Pavluk T.I., Bij Vaate A. De \& Leslie H.A. 2000: Development of an index of trophic completeness for benthic macroinverte- brate communities in flowing waters. - Hydrobiologia 437 : 135-141.

Peters W. \& Ulbrich R. 1973: The life history of the waterboatman, Trichocorixella mexicana (Heteroptera: Corixidae). - Can. Entomol. 105: 277-282.

Poisson R. 1935: Les Hémiptères aquatiques Sandaliorrhyncha Börn. de la faune française. - Arch. Zool. Exp. Génér. 77: 455-563.

PoIsSON R. \& JACZEWSKI T. 1928: Additional notes on the morphology of Stenocorixa protrusa Horváth (Heteroptera: Corixidae). - Ann. Mus. Zool. Pol. 7: 115-120.

Polegatto C.M. \& Froehlich C.G. 2001: Functional morphology of the feeding apparatus of the nymph of Ferrodes sp. (Ephemeroptera: Leptophlebiidae). — Acta Zool. 82: 165-175.

Polhemus J.T. \& Polhemus D.A. 2008: Global diversity of true bugs (Heteroptera; Insecta) in freshwater. - Hydrobiologia 595: 379-391.

Popham E.J., Bryant M.T. \& SaVAge A.A. 1984: The role of front legs of British corixid bugs in feeding and mating. - J. Nat. Hist. 18: 445-464.

Popov Y. 1971: The historical development of Hemiptera infraorder Nepomorpha (Heteroptera). - Tr. Palaeontol. Instituta SSSR No. 129, 230 pp. [in Russian].

Popov Y. 1986: Peloridiina (= Coleorrhyncha) and Cimicina (= Heteroptera) insects in the Early Cretaceous ecosystems of the West Mongolia. In Rasnitsyn A.P. (ed.): The Joint SovietMongolian Palaeontological Expedition. Moscow, pp. 50-83 [in Russian].

Popov Y. 1989: On the miocene bug genus Diacorixa, with the description of a new fossil species from Southern Germany (Insecta: Heteroptera, Corixidae). — Stuttg. Beitr. Naturk. (B) No. 156,12 pp.

PuchKova L.V. 1969: On the trophic relationships of waterboatmans and influence of Sigara striata on the water plants (Corixidae). — Zool. Zh. 48: 1581-1583 [in Russian, English abstr.].

QUADRI M.A.H. 1951: On the anatomy of the mouth-parts and the mode of feeding in the aquatic bugs (Cryptocerata). - Proc. Zool. Soc. Bengal 4: 117-135.

Ranta E. \& Espo J. 1989: Predation by the rock-pool insects Arctocorisa carinata, Callicorixa producta (Het. Corixidae) and Potamonectes griseostriatus (Col. Dytiscidae). - Ann. Zool. Fenn. 26: 53-60.

ReIlly P. \& McCARThy T.K. 1990: Observations on the natural diet of Cymatia bonsdorfi (C. Sahlb.) (Heteroptera: Corixidae): an immunological analysis. - Hydrobiologia 196: 159-166.

REYNOLDS J.D. 1975: Feeding in corixids (Heteroptera) of small alkaline lakes in central B. C. - Verh. Int. Ver. Theor. Angew. Limnol. 19: 3073-3078.

ReYnolds J.D. \& Scudder G.G.E. 1987a: Experimental evidence of the fundamental feeding niche in Cenocorixa (Hemiptera: Corixidae). — Can. J. Zool. 65: 967-973.

Reynolds J.D. \& Scudder G.G.E. 1987b: Serological evidence of realized feeding niche in Cenocorixa species (Hemiptera: Corixidae) in sympatry and allopatry. - Can. J. Zool. 65: 974-980.

Saha N., Aditya G., Bal A. \& Saha G.K. 2007: A comparative study of predation of three aquatic heteropteran bugs on Culex quinquefasciatus larvae. - Limnology 8: 73-80.

SAILOR R.I. 1948: The genus Trichocorixa (Corixidae, Hemiptera). - Univ. Kans. Sci. Bull. 32: 289-407.

SAILOR R.I. \& LiENK S.E. 1954: Insect predators of mosquito larvae and pupae in Alaska. - Mosq. News 14: 14-16. 
Savage A.A. 1989: Adults of the British aquatic Hemiptera Heteroptera. A key with ecological notes. - Sci. Publ. Freshw. Biol. Assoc. 50: 1-173.

SAVAGE A.A. 1994: The distribution of Corixidae in relation to the water quality of British lakes: A monitoring model. — Freshw. Forum 4: 32-61.

SCUDDER G.G.E. 1966: The immature stages of Cenocorixa bifida (Hung.) and C. expleta (Uhler) (Hemiptera: Corixidae). $-J$. Entomol. Soc. Br. Columbia 63: 33-40.

SCUDDER G.G.E. 1969a: The fauna of saline lakes on the Fraser Plateau in British Columbia. - Verh. Int. Ver. Theor. Angew. Limnol. 17: 430-439.

SCUDDER G.G.E. 1969b: The distribution of two species of Cenocorixa in inland saline lakes of British Columbia. - J. Entomol. Soc. Br. Columbia 66: 32-41.

SCUDDER G.G.E. 1976: Water-boatmen of saline waters (Hemiptera: Corixidae). In Cheng L. (ed.): Marine Insects. NorthHolland Publishing Company, Amsterdam, pp. 263-289.

Sivagnaname N. 2009: A novel method of controlling a dengue mosquito vector, Aedes aegypti (Diptera: Culicidae) using an aquatic mosquito predator, Diplonychus indicus (Hemiptera: Belostomatidae) in tyres. - Dengue Bull. 33: 148-160.

Skern S., ZweimÜller I. \& Schiemer F. 2010: Aquatic Heteroptera as indicators for terrestrialisation of floodplain habitats. —Limnologica 40: 241-250.

SoKol'SKAYA N.P. \& ZHITENEVA L.D. 1973: A contribution to the biology of Corixidae (Heteroptera), pests of fish culture in the Rotov district. - Zool. Zh. 52: 1330-1335 [in Russian].

Soldán T., BoJková J., VRba J., Bitušík P., ChVoJKa P., PApÁČeK M., Peltanová J., Sychra J. \& Tátosová J. 2012. Aquatic insects of the Bohemian Forest glacial lakes: Diversity, longterm changes, and influence of acidification. - Silva Gabreta 18: $123-283$.

ŠTYS P. \& JANSSON A. 1988: Check-list of recent family-group and genus-group names of Nepomorpha (Heteroptera) of the world. - Acta Entomol. Fenn. 50: 1-44.

SutTon M.F. 1945: The life-history of Corixa panzeri Fieb. Proc. Linn. Soc. Lond. 159: 51-62.

Sutton M.F. 1951: On the food, feeding mechanism and alimentary canal of Corixidae (Hemiptera, Heteroptera). - Proc. Zool. Soc. Lond. 121: 465-499.

Swart C.C., Deaton L.E. \& Felgenhauer B.E. 2006: The salivary gland and salivary enzymes of the giant waterbugs (Heteroptera; Belostomatidae). - Comp. Biochem. Physiol. (A) 145: $114-122$.

Terra W.R. \& Ferreira C. 1994: Insect digestive enzymes: properties, compartmentalization and function. - Comp. Biochem. Physiol. (B) 109: 1-62.

Tinerella P.P. 2008: Taxonomic revision and systematics of New Guinea and Oceania pygmy water boatmen (Hemiptera: Heteroptera: Corixoidea: Micronectidae). - Zootaxa 1797: 1-66.

Tomanova S., Gortia E. \& Helesic J. 2006: Trophic levels and functional feeding groups of macroinvertebrates in Neotropical streams. - Hydrobiologia 556: 251-264.

Tully S., McCarthy T.K. \& O'Donnel D. 1991: The ecology of the Corixidae (Hemiptera: Heteroptera) in the Corrib catchment, Ireland. - Hydrobiologia 210: 161-169.

UsINGER R.L. 1956: Aquatic Insects of California with Keys to North American Genera and California Species. University of California Press, Berkeley, 508 pp.

Valentini A., Miquel C., Nawaz M.A., Bellemain E., Coissac E., Pompanon F., Gielly L., Cruaud C., Nascetti G., Wincker P., Swenson J.E. \& TaberLet P. 2009: New perspectives in diet analysis based on DNA barcoding and parallel pyrosequencing: the trnL approach. - Mol. Ecol. Resour. 9: 51-60.
Vannote R.L., Minshall G.W., Cummins K.W., Sedeli J.R. \& Cushing C.E. 1980: The river continuum concept. - Can. J. Fish. Aquat. Sci. 37: 130-137.

Wachmann E., Melber A. \& DecKert J. 2006: Wanzen. Band 1. Tierwelt Deutschlands Teil 77. Goecke \& Evers, Keltern, pp. 263.

Wallace J.B. \& Merritt R.W. 1980: Filter-feeding ecology of aquatic insects. - Annu. Rev. Entomol. 25: 103-132.

Walton G.A. 1938: The British Species of Micronecta (Corixidae, Hemiptera). - Trans. Soc. Br. Entomol. 5: 259-270.

Watton G.A. 1943: The water bugs (Rhynchota - Hemiptera) of North Somerset. - Trans. Soc. Br. Entomol. 8: 231-290.

WESENBERG-Lund C. 1989: Biologie der Süßwasserinsekten. Reprint, Koeltz Scientific Books, Königstein, 682 pp.

Westwood J.O. 1871: [Corixa ovivora, sp. n.]. - Proc. Entomol. Soc. Lond. 1871: iii-iv.

Wetzel R.G. 2001: Limnology Lake and River Ecosystems. Elsevier, San Diego, 1006 pp.

Wichard W., Ahrens W. \& Eisenbeis G. 2013: Atlas zur Biologie der Wasserinsekten. Springer Spektrum, Berlin, Heidelberg, $348 \mathrm{pp}$.

WiLDERMUTH H. \& MARTENS A. 2014: Taschenlexikon der Libellen Europas. Quelle \& Meyer, Wiebelsheim, 824 pp.

Winterbourn M.J. \& Gregson K.L.D. 1981: Guide to the Aquatic Insects of New Zealand. Bulletin of the Entomological Society of New Zealand. Entomological Society of New Zealand \& New Zealand Limnological Society, Auckland, 80 pp.

WollmanN K. 1997: Vorkommen von Wasserwanzen (Corixidae, Heteroptera) in Tagebauseen der Lausitz. In Deneke R. \& Nixdorf B. (eds): Gewässerreport. Teil III Limnol. Untersuchungen im Scharmützelseegebiet von Tagebauseen Lausitz. Aktuelle Reihe BTU Cottbus, Cottbus, pp. 41-49.

Wollmann K. 2000: Corixidae (Hemiptera, Heteroptera) in acidic mining lakes with pH 3 in Lusatia, Germany. - Hydrobiologia 433: 181-183.

Wollmann K. \& Deneke R. 2002: Die räumliche Verteilung der Corixiden and ihre Bedeutung für den Stofftransport in sauren Tagebauseen. In Deneke R. \& Nixdorf B. (eds): Gewässerreport Nr 7 Tagungsband zum Workshop Biologischen Alkalinitätsproduktion Neutralisierung als Ergänzende Strategie für die Restauration von Extrem Sauren Tagebauseen. Aktuelle Reihe BTU Cottbus, Cottbus, pp. 119-124.

WróblewsKi A. 1958: Polish species of the genus Micronecta Kirk. (Heteroptera, Corixidae). - Ann. Zool. (Warszawa) 17: 247-381.

WróBlEWSKI A. 1960: Micronectinae (Heteroptera, Corixidae) of Hungary and of some adjacent countries. - Acta Zool. Acad. Sci. Hung. 6: 439-458.

WróBlewsKI A. 1980: True Bugs (Heteroptera): Freshwater Fauna of Poland. Vol. 8. Państwowe Wydawnictwo Naukowe, Poznań, Warszawa, 154 pp.

WurtsBaUGH W.A. 1992: Food-web modification by an invertebrate predator in the Great Salt Lake (USA). - Oecologia 89: 168-175.

Young E.C. 1965: Flight muscle polymorphism in British Corixidae: ecological observations. - Anim. Ecol. 34: 352-389.

Zimmermann G. 1986: Zur Phylogenie der Corixidae Leach, 1815 (Hemiptera, Nepomorpha). Unpubl. PhD Thesis, Universität Marburg, $147 \mathrm{pp}$.

ZHANG J.-F. 2010: Revision and description of water boatmen from the Middle-Upper Jurassic of Northern and Northeastern China (Insecta: Hemiptera: Heteroptera: Corixidae). — Paleontol. J. 44: 515-525.

ZWART K.W.R. 1965: On the influence of some food substances on survival of Corixidae (Heteroptera). In Freeman P. (ed.): 
Proceedings of the XIIth International Congress of Entomology. Royal Entomological Society of London, London, pp. 411-412.

Received October 5, 2016; revised and accepted February 9, 2017

Published online March 20, 2017 